\title{
МЕДИЕВАЛИСТИЧЕСКИЙ ТЕКСТ В СОВРЕМЕННОЙ РУССКОЙ ЛИТЕРАТУРЕ КАК ОТВЕТ НА ПОИСКИ ИДЕНТИЧНОСТИ ПОСЛЕ РАСПАДА СССР
}

\section{A MEDIEVALISTIC TEXT IN CONTEMPORARY RUSSIAN LITERATURE AS THE REFLECTION OF SEARCHING FOR IDENTITY AFTER THE COLLAPSE OF THE SOVIET UNION}

\author{
WITOLD PACYNO
}

\begin{abstract}
Aвstract. The aim of the article is defining the cause of popularity of medievalism in contemporary Russian literature as well as describing an impact of the images of the Middle Ages in Russian medievalist texts on the national identity after the collapse of the Soviet Union.
\end{abstract}

Keywords: Medievalism, contemporary Russian literature, myth, national identity

Witold Pacyno, Uniwersytet Jagielloński, Kraków - Polska, witoldpacyno@gmail.com

ORCID ID: 0000-0002-5833-8886

Хотя с момента распада СССР прошло уже более двадцати пяти лет, значительная часть российского общества все еще как будто живет прошлой жизнью, что сказывается на возникновении нового типа общественного сознания, определяемого как постсоветскость. Психолог и социолог Анна Шор-Чудновская, анализируя специфику постсоветского человека, употребляет определение homo postsovieticus, о котором высказывается следующим образом:

Это человек, которому по каким-то причинам не удается покинуть советскую действительность. Он охвачен своего рода фантомным состоянием, его сознание продолжает по-родственному относиться к миру, которого больше нет... [Шор-Чудновская 2009].

Определяя черты постсоветского сознания, Шор-Чудновская обращает внимание на следующие признаки homo postsovieticus:

- безрефлексивное имитирование как западных (западноевропейских), так и восточных (царской России и Советского Союза) образцов и моделей жизни;

- приобщение к массовой потребительской культуре, увлечение гламуром;

- отрицательное отношение как к „своим”, так и к „чужим”, ксенофобия;

- отсутствие доверия между людьми из-за боязни быть обманутым, преданным; 
- отсутствие рефлексии, посвященной осмыслению террора советской власти;

- атомизация и раздробленность общества, неспособность сплотиться как на частном, так и государственном уровнях;

- равнодушие к окружающему миру, в т.ч. к общественно-политической деятельности, отсутствие ответственности за частное и общественное благополучие;

- разочарованность в условиях жизни, в людях, в самих себе при одновременной пассивности и отсутствии веры в возможность улучшения условий окружающей действительности [Шор-Чудновская 2009].

Перед лицом распада государства, при невозможности отождествления себя с новыми общественно-государственными реалиями, в ситуации безрефлексивного подражания чужому (в основном западному) образу жизни и, в конце концов, при одновременном отсутствии рефлексии и попытки осмыслить травму тоталитарного режима, несомненно, можем говорить о существовании проблем с идентичностью у постсоветского российского общества. О потребности ее осознания после распада СССР пишет Татьяна Рыбальченко: „В ситуации распада советской империи осознание национальной идентичности становится экзистенциальным выбором личности, но в неменьшей степени и потребностью массового сознания" [Рыбальченко 2011: 212].

В последнее время тема идентичности является предметом бурных научных дискуссий. Василий Киселев отмечает, что после публикации работ Эдварда Сайда и Хоми Баба наступил пересмотр методологии исследования национальной идентичности, согласно которому „методологическое значение приобретала личностная идентичность с ее механизмами отнесения себя к коллективному целому, выступающему источником мировоззренческих ориентиров и ценностных стандартов" [Киселев 2010: 10-11]. В настоящей статье сосредоточимся, в основном, на национальной идентичности, в понимании которой будем ссылаться именно на утверждения Хоми Баба; по его мнению, национальная идентичность представляет собой

систему интерпретаций, конвенциональную конструкцию, для которой объективные предпосылки вроде общности языка, территории, экономического уклада и гражданских институтов есть лишь повод для знаково-символического производства, не требующего обязательной достоверности и легко замещающего действительное воображаемым или желательным [Киселев 2010: 11].

Таким образом, согласно теории Хоми Баба, национальная идентичность обладает нарративным и перформативным характером и в результате отражается в литературных текстах. Такой подход позволяет нам взглянуть на современные русские художественные тексты как на отражение поисков национальной идентичности. 
Учитывая вышесказанное, следует отметить, что современную русскую литературу, в которой в последнее время наблюдается поворот к историческому прошлому, можем считать отражением проблемы идентичности постсоветского общества. На данное явление обращают внимание многие русские теоретики и критики литературы, в частности Янина Солдаткина: „Для русской прозы 2000-2010-х годов характерно возвращение интереса к историческому повествованию" [Солдаткина, 2015: 29].

Литературный критик Наталья Иванова отмечает, что „на месте советского настоящего образовался вакуум идентичности" [Иванова, 2003: 188]. В настоящей статье выдвигаем тезис: обращение части современной русской литературы к древнерусскому средневековью является ответом на вакуум идентичности, образовавшийся после распада Советского Союза. Как отмечает Солдаткина, „для современного общества история становится тем фокусом, в котором отражаются фундаментальные национальные проблемы - формирование национальной идентичности и нравственных основ бытия, восстановление связей с прошлым..." [Солдаткина 2015: 5]. Интересными могут показаться также утверждения Томаша Наконечного, который, анализируя своеобразие русского постмодернизма, делает следующий вывод:

Поскольку этот ранний постмодернизм, точнее пре-постмодернизм, можно считать, с одной стороны, бунтом против соцреализма, а с другой - реакцией на унылую действительность 60-х и 70-х годов, постольку его зрелый период, растянувшийся во времени с середины 80-х (начало Перестройки) через полные суматохи и хаоса 90-е годы вплоть до сегодняшнего дня, соответствует восстановлению русского национального самосознания и российской государственности (перевод - W.P.) [Nakoneczny 2007: 170].

Таким образом, главной целью настоящей статьи является описание влияния образов Средневековья, запечатленных в современной русской литературе, на формирование идентичности в постсоветской России. Симптоматичный для русской литературы постсоветского периода интерес к средневековью будем рассматривать вслед за Евгением Савицким посредством понятия медиевализма [Савицкий 2015: 345-354]. Термин медиевализм (от англ. medievalism) обозначает явление, заключающееся в использовании восходящих к Средним векам, элементов, образов, тем, мотивов, сюжетов, традиций в культурах последующих эпох.

Однако при определении литературных текстов, которые могли бы считаться примером медиевализма, можно заметить некоторый разнобой.

Польская исследовательница этого явления Агнешка Крушиньска, избегая употребления англоязычного термина „медиевализм”, отдает 
предпочтение термину „средневековость” (от польск. średniowieczność) или метафоре „произведения, говорящие средневековостью” (ср. „utwory mówiące średniowiecznością") [Kruszyńska 2008]. Зато, в отличие от Крушиньской, польский исследователь Адам Регевич, хотя и употребляет понятие „медиевалистический текст” [Regiewicz 2014: 87], но в его монографии точное определение данного термина отсутствует. Поэтому в связи с всё более растущим интересом современных русских писателей к наследию эпохи средневековья, считаем введение терминов „медиевализм” и „медиевалистический текст” обоснованным. Для термина „медиевалистический текст” предлагаем следующую дефиницию: это художественный текст, характерными чертами которого являются мифологизированный образ эпохи Средневековья, использование элементов средневековой литературной традиции, а также отражение средневекового миросозерцания. Следует подчеркнуть, что не каждый медиевалистический текст обязательно содержит все эти три элемента, он может ограничиваться лишь двумя последними.

В качестве примеров описываемого явления можем перечислить следующие современные произведения: роман-житие Светланы Василенко Дурочка, роман Елены Колядины Цветочный крест, исторический роман Александра Иванова Сердие Пармы, роман Евгения Водолазкина Лавр, роман Петра Алешковского Крепость и другие. Своеобразным примером медиевализма может считаться историко-беллетристический проект Бориса Акунина под заглавием История Российского государства, часть которого затрагивает времена Древней Руси, а также массовая литература, в рамках которой Анджей Поляк, хотя и не пользуется термином медиевализм, то, тем не менее, отмечает параллельное увлечение Средневековьем:

Классические герои science fiction - изобретатели, космонавты, люди будущего - были вынуждены уступить место защищающим добро магам, волшебникам, храбрым рыцарям и обычным на вид людям, обладающими, впрочем, магическими предметами. Неизбежной была также смена антуража. Современному читателю космические корабли показались менее привлекательными, чем магические мечи, драконы и другие атрибуты псевдосредневековой действительности (перевод - W. Р.) [Polak 2017: 27].

Популярность и успех медиевалистических текстов в современной России, отражающиеся в признании как читателей, так и литературных критиков, указывают на существенность такого рода повествований для мироощущения и идентичности современного русского читателя. После распада советской государственности, в условиях девальвации общечеловеческих ценностей и традиций, исчезновения моральных ори- 
ентиров, разложения межчеловеческих отношений [см. Борисова 2014] современные русские читатели пытаются найти стабильную, аксиологически насыщенную, мировоззренческую опору, которая смогла бы восполнить возникшую духовную лакуну, отмеченную Мирчей Элиаде: „Беспрестанная десакрализация наших современников обеднила их духовную жизнь, но не смогла разбить матрицы их воображения" [Элиаде 2000: 133].

Вспьшка популярности медиевалистических текстов в постсоветской России на рубеже веков обусловлена двумя факторами. Первым является специфика эпохи средневековья. Запечатленный в художественных произведениях образ средневековья возвращает современному читателю потерянный стабильный аксиологический фундамент, который вытекает из единства тогдашнего (средневекового) миросозерцания, которое отмечает Арон Гуревич: „Сказанное означает, далее, что средневековое миросозерцание отличалось цельностью... Отсюда же проистекает и уверенность в единстве мироздания" [Гуревич 2007: 32]. Кроме того, эпоха средневековья может являться способом восполнения вышеупомянутой лакуны благодаря своей аксиологической насыщенности и духовно-религиозной направленности: „Есть основания говорить о некоторой духовной ориентации, присущей средневековью, о преобладающем на протяжении этой эпохи стиле мышления" [Гуревич 2007: 41].

Вторым фактором, детерминирующим популярность медиевалистических текстов в современной России, является его способность особенным образом влиять на национальную идентичность, а именно: благодаря использованию топоса Древней Руси, посредством которого писатели отсылают читателей к исконному прошлому русского народа, к истокам национальной культуры и истории. Польская исследовательница медиевализма Агнешка Крушиньска отмечает, что медиевализм в состоянии особенным образом оказывать воздействие на способность народа ощущать свою идентичность и отличимость [Kruszyńska 2008: 80]. Особое влияние такого рода художественных текстов на национальную идентичность возможно благодаря содержащемуся в медиевалистических текстах мифологизированному образу Средних веков, то есть мифу о Древней Руси [см. Архангельская 2014]. Рассмотрение медиевализма в мифологическом ключе позволит выявить причины его прочности в русской литературе постсоветского периода.

Однако сначала придется нам сосредоточиться на свойствах и механизмах мифа. Самым популярным предметом ностальгии человека является утраченный рай, проявляющийся в мифологических образах, о которых Мирча Элиаде пишет следующее: „С таким же успехом можно проанализировать образы... и убедиться, что они выражают ностальгию 
по мифическому прошлому, превратившемуся в архетип" [Элиаде 2000: 132]. Если эпоху Средневековья, то есть времена Древней Руси, считать архетипом, то в таком случае средневековый мир, представленный в современных медиевалистических текстах, можем считать мифологизированными образами, выражающими ностальгию по единству, потерянному в условиях современности или, скорее всего, постсовременности.

Мир мифа в духовном смысле намного богаче, чем мир обыденный, земной. Мифологические образы, в которых отражается тоска по идеально упорядоченному, но минувшему миру, всегда в состоянии выразить больше, чем человек в состоянии выразить словами: „Такие образы способны затронуть человека реальнее и ощутимей, чем любой язык аналитического склада" [Элиаде 2000: 132-133]. Тоска современного человека по тому миру невыразима и, следовательно, проявляется в возникающих в новейшей литературе образах древнерусских средних веков, которые для русского читателя кажутся не только миром идеальным и мифическим, но и прежде всего ощущаются как свои, отечественные. Мифологизированные образы отражают древнерусское прошлое, с которым современный русский читатель в состоянии идентифицироваться - как в случае древнерусской Перми и Москвы в романе Александра Иванова Сердие Пармы, древнерусского Севера в романе Евгения Водолазкина Лавp, так и в случае древнерусских княжеств, борющихся против монгольского ига в романе Петра Алешковского Крепость.

Елеазар Мелетинский отмечает другое существенное правило мифа: „Миф вообще исключает неразрешимые проблемы и стремится объяснить трудно разрешимые через более разрешимое и понятное" [Мелетинский 2005]. С точки зрения русской истории таким „трудно разрешимым" можем считать современную, то есть постсоветскую действительность. Это связано с этиологизмом мифа, так как мифологизированные образы идеального прошлого являются способом постижения нынейшней действительности. Хотя медиевалистический текст содержит образ средневекового прошлого, его цель заключается в описании и осмыслении настоящего, о чем пишет Адам Регевич:

...этот вид текста является всегда, по крайней мере, двойным голосом, относящимся к прошлому и настоящему, а заодно и к культурному источнику и действительности, изображенной в тексте" (перевод - W. P.) [Regiewicz 2014: 87].

Это видно в современных русских медиевалистических текстах, в которых Древняя Русь XV века переплетается с воспоминаниями советских и постсоветских времен (Лав $p$ Евгения Водолазкина), а времена монгольского ига представлены параллельно с унылой действительностью постсоветской России (Крепость Петра Алешковского). Медиевалистический 
текст, как и миф, направлен на осмысление настоящего через возвращение к прошлому.

Следует отметить, что обращение к мифу происходит особенно часто в сложные и переломные моменты истории, что подтверждает Наталья Ковтун: „Обращение к мифу становится насущным в кризисные периоды истории, кардинально меняющие образ мира и человека" [Ковтун 2013: 5]. Ссылаясь на Николая Конрада, Ковтун отмечает также, что характерной чертой крайних эпох является „возвратное" движение культуры, к ее собственным истокам [Ковтун 2013: 5]. Таким крайним и кризисным временем, меняющим мировоззренческие и человеческие ориентиры, можем считать перестройку и распад Советского Союза. Упомянутые исторические события, разрушившие государственные, общественные, жизненные, ценностные и мировоззренческие фундаменты российского общества, могут являться причиной актуализации мифа о Древней Руси, что сказывается на существенности и популярности медиевалистических текстов в постсоветской русской литературе.

С точки зрения идентичности, существенную роль в ее укреплении играет именно мифология:

Важным элементом в системе механизмов национальной идентификации выступает мифология... В эпоху разложения старой культуры и, особенно в период зарождения на ее обломках новой культуры устанавливается подавляющее господство мифологического типа мышления. Причем, в масштабах жизни культуры процесс этот проходит очень быстро и имеет взрывной характер: именно в это время зарождается основополагающий для новой культуры миф. В неустойчивой ситуации „переходного общества” национальная принадлежность является способом вновь ощутить себя частью некоего социального целого, найти психологическую поддержку в национальной культуре, традиции [Осмонова].

Поэтому в ситуации вакуума идентичности, образовавшегося после распада СССР, в постсоветской России миф о Древней Руси, актуализированный новейшей литературой, может восприниматься как особенно существенный для идентичности современных русских читателей. Советские мифы о светлом будущем, о созидании нового, социалистического мира и ряд других, на которых была построена советская действительность и идентичность, оказались обманом еще при советской власти, что в 60-е и 70-е годы привело к развитию так называемой деревенской прозы, во многом опирающейся на традиционное древнерусское литературное наследие [Ковтун 2013: 17]. О данном явлении Елеазар Мелетинский пишет следующее: 
Возвращение к старому после отказа от советской власти, в свою очередь, приняло и религиозно-церковные, и прямо мифологические формы, включая сюда и идеализацию дореволюционного „раннего” времени как „золотого века", и... иррациональных вер, суеверий и мифов [Мелетинский 2005].

Описанное Мелетинским возвращение к старому во многом отвечает также специфике постсоветского медиевализма, для которого свойственны как наличие мифологизированного и идеализированного образа прошлого (древнерусских времен), так и, во многих случаях, религиозная ориентация, вытекающая из специфики средневекового мировоззрения.

Необходимо подчеркнуть, что если послепетровские времена царской России часто рассматриваются как разрыв с традиционной Древней Русью, а советская мифология привела к разочарованию и оказалась миражом еще при советской власти [Ковтун 2013: 17], то сейчас в современной литературе топос Древней Руси, актуализирующий миф о Древней Руси, может оказаться куда более прочным фундаментом для современной, постсоветской мифологии и идентичности.

Однако медиевалистический текст может влиять особенным образом на идентичность не только благодаря своему мифологическому содержанию, но также благодаря обращению к истокам национальной истории и культуры. Древняя Русь, запечатленная в современных медиевалистических текстах, для постсоветского русского читателя, функционирующего в вакууме между советским прошлым и постсоветским настоящим, может стать средством для того, чтобы вновь осознать собственное происхождение (Сердие Пармы Александра Иванова) и свою особенность по отношению к другим народам, что чаще всего происходит в православном контексте (примером может послужить паломничество главного героя романа Лавр по территории католического Польского Королевства). Обращение современных писателей к временам Древней Руси способствует восстановлению культурной непрерывности, а также актуализации культурного и литературного наследия эпохи средневековья, что проявляется в использовании писателями элементов древнерусской литературной традиции, в том числе жанров жития (Дурочка Василенко, Лавр Водолазкина), патерика (Сobpeменный патерик Кучерской) или во введении героев-юродивых (Дуроч$\kappa a$, Лabp). Благодаря вышеупомянутым факторам можно утверждать, что медиевалистический текст является текстом особого рода, влияющим на национальную идентичность.

Подытоживая, следует сказать, что в ситуации аномии и всеобщего разочарования общественно-государственными реалиями и жизненными условиями в постсоветской России при одновременном нежелании 
осмыслить советскую травму, обращение русской литературы к эпохе Средневековья как к идеальному прошлому, как к эпохе со стабильным мировоззрением, насыщенной духовными и аксиологическими ценностями, неудивительно и вполне естественно. Постсоветский период и в настоящем способствует обращению к мифу - литературные мифологизированные образы средневековой Руси являются отражением того, что присутствует в подсознании постсоветского человека, но чего ему в настоящем не хватает, по чему он тоскует, и чего он не в состоянии выразить. Кроме того, для современного русского читателя древнерусское средневековье является легко узнаваемым. Это пространство, в котором он может спрятаться от проблем и жесткой действительности невыносимого настоящего:

Опять возрос голод на литературу, посвященную отечественной истории - за пределами советской истории с ее депортациями, лагерями, тюрьмами, геноцидом. Читатель устал - и отвернулся от дурной бесконечности „желтой стрелы”, предпочтя ей историю Империи: Царского двора, дворянских родов. Читатель захотел от истории - вместо дурной бесконечности и абсурда - красоты убежища... [Иванова 2003: 203].

Медиевалистические тексты могут стать для современного русского читателя именно таким красивым убежищем. Несмотря на уровень достоверности исторических событий, изображенных в медиевалистических текстах, этот особый вид художественного произведения может являться для потенциального читателя наиболее привлекательным способом познания прошлого, истории, осознания своего происхождения и ознакомления с культурным наследием, что вытекает из его мифологического содержания. Таким образом, медиевалистический текст, содержащий в себе миф о Древней Руси, можем понимать как текст, являющийся, с одной стороны, ответом на поиски национальной идентичности в современной, постсоветской России, и с другой - отражением поисков идентичности homo postsoveticus, не умеющего покинуть советское прошлое, не способного найти себе место в постсоветском настоящем.

\section{Библиография}

Архангельская А. В. 2014. Древняя Русь в сборнике повестей Бориса Акунина «Огненный перст», [в:] М. Э. Соколова, В. А. Иванова, Н. Н. Миленко, В. В. Хапаева, Н. В. Величко (ред.), Материалы Научной конференции «Ломоносовские чтения» 2014 года и Международной научной конференции студентов, аспирантов и молодых ученых «Ломоносов-2014», Севастополь: Экспресс-печать, электронный ресурс: https:/ istina.msu.ru/publications/article/6223739/ (доступ 17.08.2017). 
Борисова Ю. В. 2014. Социальное самочувствие и экономическая интеграция в сознании постсоветского человека, [в:] М. В. Назукина, О. Б. Подвинцев, Н. А. Коровникова (ред.), Постсоветская идентичность $b$ политическом измерении: реалии, проблемы, перспективы. Материалы Всероссийской научно-практической Интернет-конореренциии, Пермь: Гармония.

Гуревич А. 2007. Избранные труды. Средневековый мир, Санкт-Петербург: Издательство Санкт-Петербургского университета.

Иванова, Н. Б. 2003. Скрытый сюжет. Русская литература на переходе через век, Санкт-Петербург: Русско-Балтийский информационный центр БЛИЦ.

Киселев В. С. 2011. Мультикультурализм в литературном измерении: проблемы и перспективы развития в российском митературоведении, [в:] Т. Л. Рыбальченко (ред.), Проблемы национальной идентичности в русской литературе ХХ века, Томск: Издательство Томского университета.

Ковтун Н. В. 2013. Современная традиционалистская проза: идеология и мифопоэтика, Красноярск: СФУ.

Мелетинский Е. 2005. Миф и двадицатый век, электронный pecypc: http://polit.ru/ article/2005/12/19/meletinsky/ (доступ 10.08.2017).

Осмонова Н. И. Культурные основания мифа как фактора национальной идентификации, электронный ресурс: http://anthropology.ru/ru/text/osmonova-ni/kulturnyeosnovaniya-mifa-kak-faktora-nacionalnoy-identifikacii (доступ 17.08.2017).

Рыбальченко Т. Л. 2011. Национальное как тайна архачческого и как мистификация в прозе Владислава Отрошенко, [в:] Т. Л. Рыбальченко (ред.), Проблемы национальной идентичности в русской митературе ХХ века, Томск: Издательство Томского университета.

Савицкий Е. 2015. „Новый медиевализм” четверть века спустя, „Новое литературное обозрение", № 5 (135).

Солдаткина Я. В. 2015. Современная словесность: актуальные тенденции в русской литературе и журналистике, Москва: МПГУ.

Шор-Чудновская А. 2009. Понять постсоветского человека, „Неприкосновенный запас", № 6 (68), электронный ресурс: http://magazines.russ.ru/nz/2009/6/an16. html (доступ 8.08.2017).

Элиаде М. 2000. Избранные сочинения: Миф о вечном возвращении; Образы и символы; Священное и мирское, Москва: Ладомир.

Kruszyńska A. 2008. Średniowieczność w literaturze i kulturze XX wieku. Propozycje badawcze, Pułtusk: Akademia Humanistyczna im. A. Gieysztora.

Nakoneczny T. 2007. Rosyjska tożsamość narodowa a literatura postmodernizmu, [в:] A. Gleń, I. Jokiel, M. Szladowski (ред.), Literatura i/a tożsamość w XX wieku, Opole: Uniwersytet Opolski.

Polak A. 2017. Fantastyka ćwierć wieku po przełomie, „Przegląd Rusycystyczny”, № 2 (158).

Regiewicz A. 2014. Mediewalizm wobec zjawisk audiowizualnych i nowych mediów, Warszawa: Wydawnictwio DiG. 